\title{
Temporal and microtopographical variations in greenhouse gas fluxes from riparian forest soils along headwater streams
}

Teresa K. Silverthorn ( $\square$ teresa.silverthorn@alumni.ubc.ca )

The University of British Columbia https://orcid.org/0000-0001-6152-6573

John S. Richardson

UBC: The University of British Columbia

\section{Research Article}

Keywords: Carbon dioxide, Biogeochemical cycling, Methane, Nitrous oxide, Riparian zone

Posted Date: May 26th, 2021

DOl: https://doi.org/10.21203/rs.3.rs-303219/v1

License: (c) (1) This work is licensed under a Creative Commons Attribution 4.0 International License. Read Full License

Version of Record: A version of this preprint was published at Biogeochemistry on July 12th, 2021. See the published version at https://doi.org/10.1007/s10533-021-00832-5. 


\section{Abstract}

Riparian zones of headwater streams have valuable ecosystem functions and are prevalent across many landscapes. Nevertheless, studies of greenhouse gas (GHG; CO $2, \mathrm{CH} 4, \mathrm{~N} 2 \mathrm{O}$ ) fluxes from these unique ecosystems, with fluctuating water tables and high soil organic matter, remain limited. Our objectives were to (1) to quantify the effects of local riparian groundwater conditions on soil GHG flux rates, namely to determine if groundwater discharge (DIS) areas in the riparian zone would have higher soil moisture than adjacent non-discharge (ND) areas in the riparian zone, impacting GHG fluxes; and (2) to examine the relationship between GHG fluxes, soil moisture, soil temperature, and groundwater depth. We measured gas fluxes in situ alongside two relatively undisturbed headwater streams over one year, using closed static chambers and gas chromatography. We found that, although not significant, DIS areas had on average lower $\mathrm{CH} 4$ uptake and lower $\mathrm{CO} 2$ emissions than ND areas. We further found that soil temperature explained $30.0 \%$ and $26.2 \%$ of variation in CO 2 and $\mathrm{N} 2 \mathrm{O}$ fluxes, respectively, and soil moisture explained $9.8 \%$ of variation in $\mathrm{CH} 4$ fluxes. Our results provide information on the magnitude and drivers of GHG fluxes in riparian zones to help inform GHG budgets and forest management.

\section{Introduction}

Soils play an important role in climate change as they can sequester carbon or be sources of greenhouse gases (GHGs) to the atmosphere, depending on the conditions (Lal et al. 2015; Oertel et al. 2016). Improving our understanding of the environmental controls on the rates of GHG fluxes to the atmosphere is important for reducing uncertainty in global estimates of carbon cycling to help mitigate climate change (Oertel et al. 2016; Sun et al. 2013). The production of three important greenhouse gases emitted from soils, i.e. carbon dioxide $\left(\mathrm{CO}_{2}\right)$, methane $\left(\mathrm{CH}_{4}\right)$, and nitrous oxide $\left(\mathrm{N}_{2} \mathrm{O}\right)$, is strongly controlled by environmental factors such as soil temperature and soil moisture (Luo and Zhou 2006).

While several studies have evaluated GHG fluxes from forests (as summarized in Dalal and Allen [2008] and Oertel et al. [2016]), studies examining GHG emissions from riparian forests remain limited (Goodrick et al. 2016; Soosaar et al. 2011). Moreover, the majority of riparian GHG flux research has been conducted in the riparian zone of wetlands (Audet et al. 2013; Nag et al. 2017), or if the focus was on streams they were in an agricultural context (Fisher et al. 2014; Skinner et al. 2014). Moreover, many of these studies only focus on $\mathrm{CO}_{2}$, neglecting $\mathrm{CH}_{4}$ and $\mathrm{N}_{2} \mathrm{O}$ (Tufekcioglu et al. 2001).

The ecosystem for this study, the riparian zones of headwater streams in south-western British Columbia, was chosen for its unique conditions and ecological importance. Riparian zones, that is, the three dimensional zones of direct interaction between terrestrial and aquatic ecosystems (Gregory et al. 1991), are important for nutrient cycling (Hinshaw and Dahlgren, 2016), biodiversity (Ramey and Richardson, 2017), and carbon sequestration (Hazlett et al. 2005). A large proportion of nutrients (e.g. nitrogen and DOC) from upland soils are transferred to riparian ecosystems, where they can drive denitrification (Pinay et al. 2018) and methanogenesis (Fiedler et al. 2005). Moreover, carbon storage generally increases with wetter conditions where decomposition of organic matter is limited by oxygen, thus decreasing soil 
respiration (Gundersen et al. 2010). Due to the typically moist conditions as a result of the influence of surface and belowground water, riparian zones can sequester more carbon than many upland forests (Gundersen et al. 2010). Conversely, due to their shallow and fluctuating water tables (Goodrick et al. 2016), hydromorphic (wet) soils (Gundersen et al. 2010), and high soil organic matter content, riparian zones have the potential to contribute significant amounts of $\mathrm{CH}_{4}$ and $\mathrm{N}_{2} \mathrm{O}$ to the atmosphere, two GHGs with high global warming potentials (Christiansen et al. 2012; Vidon et al. 2018). For example, after taking into account soils with intermediate aeration conditions, which covered only $34 \%$ of the land area, mean annual $\mathrm{N}_{2} \mathrm{O}$ emission rate for a forest in southwest Germany doubled (Jungkunst et al., 2004).

Small streams occur at a high density in forested landscapes of the Pacific Northwest, with about $2.5 \mathrm{~km}$ of stream length per square kilometer (Richardson et al. 2005). Therefore, given the extent and distinctive conditions of forested riparian zones, the GHG fluxes from these soils may represent a significant proportion of gas fluxes from forests. Additionally, due to the unique conditions of riparian ecosystems, the drivers of gas fluxes may differ from those in non-riparian areas (Goodrick et al. 2016). As such, this research examines an important gap in the literature, and the results of this research can help support the management of riparian areas to contribute to climate change mitigation.

Given that riparian zones may be hotspots of GHG fluxes to the atmosphere, it is critical to improve our understanding of the magnitudes, as well as the spatial and temporal variability, of GHG fluxes in these systems. Soil moisture and soil temperature have a strong influence on the ecosystem processes driving GHG emissions, thus seasonal variation can impact gas fluxes (Sun et al. 2013). Improving our understanding of these seasonal dynamics of GHG fluxes in riparian zones of headwater streams will contribute to more accurate GHG budgets for these understudied ecosystems (Sun et al. 2013).

Landscape features that influence soil characteristics, such as local microtopography and hydrogeomorphic setting, can be important for predicting riparian GHG emissions. These features may affect the spatial distribution of soil moisture, nutrients, and organic matter, thus consequently impacting the magnitude of GHG emissions (Jacinthe and Vidon, 2017; Soosaar et al. 2011). Local groundwater discharge conditions may create particularly important microsite variation in the riparian zones of streams. Groundwater discharge (DIS) areas, or discrete riparian inflow points, are the result of uplandoriginating groundwater converging and discharging in a topographic depression in the riparian zone (Kuglerová et al. 2014). Soil conditions at DIS areas have been found to have higher base cation and nitrogen concentrations, soil moisture, and $\mathrm{pH}$ levels when compared to surrounding non-groundwater discharge (ND) areas (Giesler et al. 1998). These soil conditions may influence the processes controlling soil GHG fluxes along headwater streams.

In this study, we evaluated the spatial and temporal variation of annual soil GHG fluxes from the forested riparian zone of two relatively undisturbed headwater streams in south-western British Columbia, Canada, over one year. The objectives were (1) to quantify the effects of local riparian groundwater conditions on soil GHG flux rates, namely to determine if higher soil moisture in DIS areas than ND areas, due to 
groundwater influence, impacts GHG fluxes; and (2) to examine the relationship between GHG fluxes, soil moisture, soil temperature, and groundwater depth, over one year.

\section{Methods}

\subsection{Site description}

Study sites were located in Malcolm Knapp Research Forest (MKRF), at the foothills of the Coast Mountains, about $40 \mathrm{~km}$ east of Vancouver, British Columbia $\left(49^{\circ} 16^{\prime} \mathrm{N}, 122^{\circ} 34^{\prime} \mathrm{W}\right)$. The biogeoclimatic zone is Coastal Western Hemlock (Klinka et al. 2005), and the dominant tree species are Western Hemlock (Tsuga heterophylla), Douglas-fir (Pseudotsuga menziesii), and Western Red Cedar (Thuja plicata) (Klinka et al. 2005). The forest is mostly comprised of approximately 90-year-old, second growth, naturally regenerated following widespread fire in 1925, and again in 1931 (Klinka et al. 2005). We measured gas fluxes from riparian soils along two relatively undisturbed streams (Mike Ck. and Upper East $\mathrm{Ck}$.), which have not have any forest harvest, or other major anthropogenic disturbances, in their catchment areas since the 1931 wildfire (Kiffney et al. 2003). Both streams flowed predominantly southwards, and they met Richardson and Danehy's (2007) criteria for a headwater stream with a relatively small catchment area under 100 ha as well as a narrow stream width (Table 1).

The climate is maritime, with slight continental influence due to the mountains and inland location (Klinka et al. 2005). The primary climate (Köppen) classification is $\mathrm{Cfb}$, temperate oceanic climate (Kottek et al. 2006). The climate is characterized by moderate temperatures, with wet, mild winters, and cool, relatively dry summers (Klinka et al. 2005). Mean annual precipitation and temperature at the Environment Canada climate station located at the Research Forest (Haney UBC RF Admin, station number 1103332 ) are $2131 \mathrm{~mm}$ and $9.7^{\circ} \mathrm{C}$, respectively (data for 1962 to 2006). Over the duration of our study, the highest daily average air temperature was $17.0^{\circ} \mathrm{C}$ in August at Mike Ck., and the lowest daily average air temperature was $0.7^{\circ} \mathrm{C}$ in March at Upper East Ck. (excluding the 10-day period in January, which was possibly even colder).

Glacial till and colluvium are the predominant parent materials in MKRF (Klinka, 1976). In the southern portion, where our sites were located, surficial deposits include glacio-fluvial and glacio-marine deposits from Pleistocene era glaciation, overlaying compacted till or bedrock (Klinka et al. 2005; Klinka, 1976). The soils formed on these materials are shallow and can be expected to be coarse, acid, and low in basic cations (Klinka et al. 2005). The soils at both sites were designated a Humo-Ferric Podzol.

\subsection{Greenhouse gas and soil sampling}

The net soil-atmosphere exchange of $\mathrm{CO}_{2}, \mathrm{CH}_{4}$, and $\mathrm{N}_{2} \mathrm{O}$ was measured using closed, static chambers (Fig. A.2 in the Supplementary Information). Sampling occurred on a weekly basis from May to September 2019, and on an approximately monthly basis from October 2019 to May 2020, in order to capture an annual cycle of GHG fluxes. We decreased the frequency of sampling in the winter months because winter emission rates are expected to be a small proportion of the annual emission budget in 
temperate climates, since root respiration and microbial activity is low due to the cold temperatures; we also expect limited emission pulses from freeze-thaw events in our study area since the soils rarely freeze (Oertel et al., 2016). In all figures, weekly flux rate values are averaged to a monthly value.

At each site, six chambers were placed along the study reach (for a total of twelve chambers included in the study), on level ground, about 1 to $2 \mathrm{~m}$ from the stream bankfull margin, in order to capture an area within the zone of influence of the stream (Gregory et al. 1991). Chambers (diameter of $30.5 \mathrm{~cm}$, height of $23 \mathrm{~cm}$ ) made of grey PVC pipe were permanently inserted about $10 \mathrm{~cm}$ below the soil surface, for an average headspace volume of $9.6 \mathrm{~L}$. Chambers were installed at least 10 days (on average 23 days) prior to the first gas sampling to reduce the effects of soil and root disturbances.

At each site, the chambers were stratified according to local groundwater discharge conditions, with half of the chambers in distinct in groundwater discharge (DIS) and half in non-groundwater discharge (ND) microsites, in order to account for some of the high spatial variability associated with GHG fluxes from soils (Vidon, Marchese, Welsh, and McMillan, 2015). These DIS areas, or discrete riparian inflow points, occur when upland-originating groundwater converges and discharges in a depression in the topography of the riparian zone (Kuglerová et al. 2014). The DIS areas were identified in Arcmap 10.6.1 using a $1 \mathrm{~m}$ digital elevation model (DEM) and flow accumulation modelling using a channelization threshold of 1 ha. This modelling process assumes that topography and gravity control water movement, and that the groundwater flow path follows the ground surface (Kuglerová et al. 2014). The DIS areas were then confirmed with field observations of topography, wetness, and hydrophilic vegetation. Based on the groundwater-table level data from the wells installed at each chamber, two DIS areas were re-classified after the fact in cases where the well was dry for at least $80 \%$ of the sampling occasions, resulting in a final total of four replicates of DIS areas and eight replicates of ND areas.

During gas sampling, a white PVC lid was placed on top of the chamber and headspace air samples were taken at $0,15,30$, and 45 minutes after closure. Headspace air samples of $20 \mathrm{~mL}$ were taken from a rubber septum sampling port in the middle of the lid using a 23 gauge needle and a $50 \mathrm{~mL}$ syringe after pumping $20 \mathrm{~mL}$ of the headspace gas twice to facilitate mixing. The gas sample was then injected into a pre-evacuated $12 \mathrm{~mL}$ exetainer (LabCo Ltd., Lampeter, Wales) until over-pressurized. After gas sampling, air temperature of the headspace was recorded and two ambient air samples were taken for reference. Sampling at a site was performed over approximately one hour, between 9:15 and 16:30 $\mathrm{h}$ to capture daily flux rates. Gas samples were analysed on a 7890A gas chromatograph (Agilent Technologies Inc., CA, USA) equipped with a flame ionization detector and an electron capture detector (Agilent Technologies Inc., CA, USA).

On each gas sampling date, volumetric soil moisture was recorded at each chamber using a ProCheck portable probe (Decagon Devices, Inc., Washington, USA) by using the mean of three readings, each no more than $0.5 \mathrm{~m}$ from each chamber. The depth to the groundwater table was also measured on each sampling date by blowing into a thin tube attached to a meter stick lowered into a well, until the bubbling noise of the groundwater was heard. The corresponding distance from the groundwater to the top of the 
well, as well as the distance from the soil surface to the top of the well were noted, in order to calculate the depth to the groundwater table. The wells were made of perforated PVC pipe wrapped in landscape fabric installed at least $40 \mathrm{~cm}$ deep into the soil. Over the entire sampling period, continuous soil temperature readings were taken at $1 \mathrm{hr}$ intervals using iButton ${ }^{\circledR}$ dataloggers (DS1992L- Thermochron and DS1923- Hygrochron, Maxim Integrated Products, USA) buried about $10 \mathrm{~cm}$ below the soil surface. Two iButtons were buried a few metres from the most upstream chamber at Upper East Ck. and the most downstream chamber at Mike Ck.; one at $0.5 \mathrm{~m}$ and the other at $1.5 \mathrm{~m}$ from the bankfull stream width. The other two iButtons were buried beside two chambers (one in a DIS and one in a ND area) at each site, no more than 0.5 from the chamber. Due to an error, the latter two iButtons only recorded until November 2019. Soil temperature measurements for the period of January 12 to January 22, 2020 were excluded from analysis due to data logger malfunction. Air temperature was measured at each site using two HOBO U23 Pro v2 data loggers (Onset Computer Corporation, MA, USA) located $0.5 \mathrm{~m}$ and $1.5 \mathrm{~m}$ from the stream bankfull width at each study reach. The data were divided into seasons using the days of the spring and fall equinox, and summer and winter solstice.

\subsection{Statistical analysis}

Gas flux rates were calculated by linear regression of gas concentrations over time. Each time series was evaluated for goodness of fit by visual inspection (Collier et al. 2014). Additional quality control measures included visual inspection for abnormally high and low values outside the range of reported riparian emissions, as well as Cook's Distance statistical test (Zuur et al. 2007). In sum, these quality control measures resulted in the removal of $11 \%$ of flux rate estimates for $\mathrm{CO}_{2}, 7 \%$ for $\mathrm{CH}_{4}$, and $27 \%$ for $\mathrm{N}_{2} \mathrm{O}$. Our final dataset had 192, 138, and 153 flux rate estimates for $\mathrm{CO}_{2}, \mathrm{CH}_{4}$, and $\mathrm{N}_{2} \mathrm{O}$, respectively. Using the ideal gas law, the flux rate was converted to $\mu \mathrm{mol}$, and then the molecular mass was used to translate this value into $\mu \mathrm{g}$ or $\mathrm{mg}$ following Collier et al. (2014). For statistical analysis, we used the software R3.6.1 ( $\mathrm{R}$ Core Team, 2020, using "glmmTMB" (Brooks et al. 2017) for the linear mixed effects (LME) models, and "variancePartition" to calculate the relative importance of variables (Hoffman and Schadt 2016). The models included the response variable of gas flux rate (or environmental variables) and the fixed effect of the environmental variables or landscape position, and the $A R(1)$ autoregressive covariance structure to account for temporal autocorrelation and repeated measures (Kravchenko and Robertson 2015). Annual GHG emission rates were estimated from the sum of weekly average emission rates, and should be regarded as approximations since weekly to monthly 45-minute chamber-based measurements may miss important sources of variation. Weeks with missing data were interpolated from previous and subsequent weeks' data. All of the models met the assumptions of normality and homogeneity of variance. For all statistical analyses, significance was accepted at $p<0.05$.

We acknowledge that our statistical models are pseudoreplicated as we only examined two streams, thus limiting statistical inference and universality of the results. As such, the results should be considered as a case study. However, we can still glean important information, particularly as the dynamics of GHG fluxes from riparian areas of headwater streams is an understudied area of research. 


\section{Results}

\subsection{Environmental variables}

On average, soil moisture and soil temperature were higher, and the depth to the groundwater table was lower in the DIS areas. The mean daily soil temperature was $14.6 \pm 1.3^{\circ} \mathrm{C}$ at the DIS area loggers and $14.0 \pm 1.1^{\circ} \mathrm{C}$ at the ND area loggers (until November 2019; Fig. $1 \mathrm{~A} ; p=0.65$ ). The mean annual soil temperature was $8.6 \pm 4.4^{\circ} \mathrm{C}$ (mean $\pm S D$ ) at Mike Ck. and $8.2 \pm 4.7^{\circ} \mathrm{C}$ at Upper East Ck. The average daily range in soil temperature was $0.69 \pm 0.55^{\circ} \mathrm{C}$, across both sites. When averaged across the two sites, mean daily soil temperature was $14.3 \pm 1.1^{\circ} \mathrm{C}$ in the summer, $7.7 \pm 2.8$ in the fall, $7.3 \pm 3.1$ in the spring, and $4.1 \pm 1.3^{\circ} \mathrm{C}$ in the winter. For a summary of weekly maximum and minimum values for soil temperature, soil moisture, and depth to the groundwater table refer to Table A. 1 in Supplementary Information.

Annual mean soil moisture was 1.16 times higher at the DIS areas ( $54.3 \pm 9.5 \%)$ than at the ND areas $(46.8 \pm 13.6 \%$ ) (Fig. 1B; $p=0.17$ ). The mean annual soil moisture at the Mike Ck. and Upper East Ck. sites was $52.5 \pm 11.8 \%$ and $44 \pm 12.5 \%$, respectively. The highest measured mean soil moisture was $76 \%$ in December at Upper East Ck., and the lowest mean soil moisture was 5.6\% in May at Mike Ck. When averaged across the two sites, mean soil moisture was $55.4 \pm 10.2 \%$ in the winter, $51.9 \pm 11.5$ in the fall, $49.4 \pm 12.4 \%$ in the spring, and $46.8 \pm 13.4 \%$ in the summer.

On average over the year, the water table was closer to the soil surface at the DIS areas $(26.2 \pm 9.8 \mathrm{~cm})$ compared to the ND areas $(27.5 \pm 9.5 \mathrm{~cm}$ ) (Fig. 1C, $p=0.99)$. In the fall, the season with the shallowest mean groundwater table level, the groundwater table was closer to the soil surface in the DIS $(20.1 \pm 12.4$ $\mathrm{cm})$ areas compared to the ND $(23.2 \pm 11.6 \mathrm{~cm})$ areas. In the spring, the season with the deepest mean groundwater table level, the mean levels in the DIS $(28.9 \pm 6.6 \mathrm{~cm})$ and ND $(28.7 \pm 9.2 \mathrm{~cm})$ areas were similar. The mean annual depth to the groundwater table for Mike Ck. and Upper East Ck. was $27.1 \pm 8.1$ $\mathrm{cm}$ and $26.7 \pm 12.5 \mathrm{~cm}$, respectively. The highest water table depth was $2 \mathrm{~cm}$ above the ground surface (flooding) on a rainy day in June at a DIS area at Mike $\mathrm{Ck}$. The water table was deeper than what the well could measure on $35 \%$ of sampling occasions, which occurred most often (48\%) in the summer. When averaged across the two sites, the mean depth to the groundwater table was $28.8 \pm 8.2 \mathrm{~cm}$ in the spring, closely followed by $28.4 \pm 8.3 \mathrm{~cm}$ in the summer and $27.5 \pm 9.5 \mathrm{~cm}$ in the winter. The shallowest mean seasonal depth to the groundwater table was $22.1 \pm 11.8 \mathrm{~cm}$ in the fall.

\subsection{Spatial and temporal variation in greenhouse gas fluxes}

On average, $\mathrm{CO}_{2}$ emission rates $\left(\mathrm{mg} \mathrm{CO}_{2}-\mathrm{C} \mathrm{m}^{-2} \mathrm{~h}^{-1}\right)$ were 1.35 times lower in DIS areas $(48.8 \pm 27.5)$ compared to the ND areas (65.7 $\pm 35.8 ; \mathrm{Fig} .2 \mathrm{~A} ; p=0.10)$. Methane uptake rates $\left(\mu \mathrm{g} \mathrm{CH}_{4}-\mathrm{C} \mathrm{m}^{-2} \mathrm{~h}^{-1}\right)$ were 1.71 times lower in DIS $(-17.0 \pm 11.7)$ areas compared to the ND areas $(-29.1 \pm 19.3$; Fig. $2 \mathrm{~B} ; p=0.10)$. There was no difference in the $\mathrm{N}_{2} \mathrm{O}$ average annual flux $\left(\mu \mathrm{N} \mathrm{N}_{2} \mathrm{O}-\mathrm{N} \mathrm{m}^{-2} \mathrm{~h}^{-1}\right)$ between the DIS $(2.7 \pm 2.8)$ and ND areas $(2.7 \pm 2.8$; Fig. $2 \mathrm{C} ; p=0.91)$. Although none of the $\mathrm{GHG}$ flux rates were statistically 
significantly different between DIS and ND areas according to our LME models (Table A.2 in Supplementary Information).

The seasonal trend in $\mathrm{CO}_{2}$ fluxes was similar at both the DIS and ND areas. ND areas had a consistently greater seasonal average rates of $\mathrm{CO}_{2}$ fluxes than DIS areas (Fig. 2A; Table A.3 in Supplementary Information). The seasonal trend in $\mathrm{CH}_{4}$ fluxes was mostly the same at both the DIS and ND areas. ND areas had consistently greater seasonal average rates of $\mathrm{CH}_{4}$ uptake than DIS areas (Fig. 2B; Table A.3). The seasonal trend in $\mathrm{N}_{2} \mathrm{O}$ fluxes was dissimilar between the DIS and ND areas (Fig. 2C; Table A.3).

According to the LME models, soil temperature was a significant predictor of $\mathrm{CO}_{2}$ and $\mathrm{N}_{2} \mathrm{O}$ fluxes, where a degree increase in soil temperature resulted in $4.4 \mathrm{mg}$ increase in $\mathrm{CO}_{2}$ emissions and a $0.34 \mu \mathrm{g}$ increase in $\mathrm{N}_{2} \mathrm{O}$ fluxes (Fig. 3; Table A.3). The marginal $\mathrm{r}^{2}$ values for the soil temperature models for $\mathrm{CO}_{2}$ and $\mathrm{N}_{2} \mathrm{O}$ were 0.78 and 0.67 , respectively. The analysis of variance partitioning of the environmental variables showed that soil temperature explained $30.0 \%$ of the variation in $\mathrm{CO}_{2}$ fluxes and $26.2 \%$ of the variation in $\mathrm{N}_{2} \mathrm{O}$ fluxes (Table A.4 in Supplementary Information). Soil moisture was a significant term in the model explaining $\mathrm{CH}_{4}$ (explaining $9.8 \%$ of variation) and $\mathrm{N}_{2} \mathrm{O}$ fluxes (explaining $13.8 \%$ of variation). For every percent increase in soil moisture, $\mathrm{CH}_{4}$ fluxes increased by $0.35 \mu \mathrm{g}$, and $\mathrm{N}_{2} \mathrm{O}$ fluxes increased by $0.1 \mu \mathrm{g}$. The marginal $\mathrm{r}^{2}$ values for the soil moisture models for $\mathrm{CH}_{4}$ and $\mathrm{N}_{2} \mathrm{O}$ were 0.14 and 0.23 , respectively. Additionally, depth to the groundwater table was a significant term in the model explaining $\mathrm{N}_{2} \mathrm{O}$ fluxes, with a marginal $r^{2}$ of 0.14 . For every centimeter increase in depth to the groundwater table, $\mathrm{N}_{2} \mathrm{O}$ fluxes increased by $0.06 \mu \mathrm{g}$. The relative importance of the DIS/ND term was relatively low in all cases, but was most important for $\mathrm{CH}_{4}(8.5 \%)$.

\section{Discussion}

The riparian forest soils in this study were on average a net $\mathrm{CO}_{2}$ and $\mathrm{N}_{2} \mathrm{O}$ source, and $\mathrm{CH}_{4}$ sink. The estimated cumulative annual (hereafter referred to as annual) $\mathrm{CO}_{2}$ emission rate from soils in this study $\left(4,194 \mathrm{~kg} \mathrm{CO}_{2}-\mathrm{C} \mathrm{ha}^{-1} \mathrm{yr}^{-1}\right)$ was similar to the reported averages for wetlands $(4,130)$ and boreal forests $(3,220)$ (Luo and Zhou 2006). Our estimated annual $\mathrm{CH}_{4}$ uptake rate $\left(-2.1 \mathrm{~kg} \mathrm{CH}_{4}-\mathrm{C} \mathrm{ha}^{-1} \mathrm{yr}^{-1}\right)$ was similar to the reported averages for temperate grasslands (-3.2), boreal forests (-1.9), and deserts (-2.1), (Dalal and Allen 2008). Riparian areas tend to have shallow water tables and higher soil moisture levels than upland ecosystems, similar to wetland ecosystems (Vidon et al. 2018). Nevertheless, the $\mathrm{CH}_{4}$ flux rates in this study were more similar to values for forests than wetlands, which are often sources of $\mathrm{CH}_{4}$ (Dalal and Allen 2008). Our estimated annual $\mathrm{N}_{2} \mathrm{O}$ flux rate $\left(0.2 \mathrm{~kg} \mathrm{~N}_{2} \mathrm{O}-\mathrm{N} \mathrm{ha}^{-1} \mathrm{yr}^{-1}\right)$ was similar to, but lower than, the reported averages for boreal forests (0.4) and deserts (0.5) (Dalal and Allen 2008). A few studies have reported similarly low annual $\mathrm{N}_{2} \mathrm{O}$ flux rates $\left(\mathrm{kg} \mathrm{N}_{2} \mathrm{O}-\mathrm{N} \mathrm{ha}^{-1} \mathrm{yr}^{-1}\right)$, including a temperate forest in Japan (0.2) (Morishita et al. 2007), a boreal forest in Finland (0.04) (Pihlatie et al. 2007), and a swamp forest in Indonesia (0.3) (Furukawa et al. 2005). 
There are very few studies of GHG emissions that are explicitly reported for the riparian zones of headwater streams (e.g. Leith et al. 2015). Often stream order, stream width, or catchment size are not reported, so the designation of a headwater stream cannot be determined (Richardson and Danehy 2007). This apparent lack of studies alongside headwater streams represents a gap in the literature, given the ubiquity of headwater streams across many landscapes and their vulnerability to human disturbance (Richardson, 2020).

\subsection{Spatial variation in greenhouse gas fluxes}

While none of the GHG flux rates were significantly different between the DIS and ND areas, there were several pieces of evidence that provided support for the mechanisms underlying our hypothesis that DIS areas would have higher soil moisture due to groundwater influence compared to ND areas, resulting in greater anaerobically produced $\mathrm{CH}_{4}$ and $\mathrm{N}_{2} \mathrm{O}$ emissions and lower aerobically produced $\mathrm{CO}_{2}$ emissions. Methane uptake was on average 1.71 times lower, and $\mathrm{CO}_{2}$ emission rates were 1.35 times lower, at the DIS areas than the ND areas. The water table and soil moisture were on average 1.05 and 1.16 times higher, respectively, at the DIS sites compared to the ND sites. Additionally, the variation in soil moisture was greater in the ND areas than the DIS areas, potentially indicating a stabilizing influence of groundwater inputs. These conditions in DIS areas are likely a result of upland-originating groundwater converging and discharging in a depression in the riparian zone (Kuglerová et al. 2014). This trend in variability was also reflected in the GHG flux rates, where variability was consistently higher at the ND areas than the DIS areas across seasons for $\mathrm{CO}_{2}$ and $\mathrm{CH}_{4}$, and $\mathrm{N}_{2} \mathrm{O}$ (Table A.3).

Nitrous oxide emission rates were on average higher at the DIS than the ND areas, except in the summer. When accounting for the wet forest soils that made up less than half of a catchment in Denmark, the global warming potential from $\mathrm{N}_{2} \mathrm{O}$ and $\mathrm{CH}_{4}$ more than doubled (Christiansen et al. 2012). Other studies have found variations in $\mathrm{GHG}$ emission rates based on soil water content. For instance, soil moisture explained $65 \%$ and $45.8 \%$ of variation in $\mathrm{CO}_{2}$ and $\mathrm{CH}_{4}$ fluxes, respectively, from peat bogs in the Pacific coastal temperate rainforest of Canada (Levy-Booth et al. 2019). In central Indiana, the topographical depressions only covered $<8 \%$ of the land area, but accounted for $78 \%$ of annual $\mathrm{CH}_{4}$ emissions (Jacinthe et al. 2015). Depending on the local conditions, $\mathrm{CO}_{2}$ emissions may not always be limited in riparian zones. Porewater $\mathrm{CO}_{2}$ concentrations across a riparian hillslope transect of a headwater stream in Sweden were on average higher in the riparian zone than in the hillslope, likely due to enhanced productivity in the riparian zone and greater mobilization of $\mathrm{CO}_{2}$ due to the generally wetter conditions found in riparian zones (Leith et al. 2015).

The lack of a significant difference in flux rates between the DIS and ND areas, may be because the soil moisture is already relatively high in the riparian zone of headwater streams in southwestern British Columbia, due to the wet climate and interaction with the stream channel (Moore et al. 2005). Therefore, the additional moisture in the DIS areas may not play as important of a role in predicting GHG emissions as it might in a more arid landscape, such as Spain (Poblador et al. 2017), where the mean depth to the 
groundwater table was $54 \mathrm{~cm}$ in a headwater catchment, compared to $27 \mathrm{~cm}$ in our study. Alternatively, the lack of significant difference in flux rates between the DIS and ND areas may have been due to the large spatial variation within both the DIS and ND areas, and too few spatial replicates.

In contrast to the results of this study, in a parallel study (Silverthorn and Richardson 2021), we found that $\mathrm{CH}_{4}$ uptake was significantly lower in DIS areas. In addition to the reference streams examined in this study, our parallel study considered riparian zones of streams running through harvested forest stands (with and without a riparian buffer zone). Therefore, although $\mathrm{CH}_{4}$ uptake may not be statistically significantly lower in the DIS areas of relatively undisturbed riparian zones, DIS areas had lower $\mathrm{CH}_{4}$ uptake (and were a $\mathrm{CH}_{4}$ source more often) than ND areas under disturbed ecosystem conditions. An explanation for this discrepancy could be that forest harvest causes generally drier surface soil due to increased evaporation from the solar radiation coming in to the riparian zone (Moore et al. 2005). At the same time clear-cutting causes a rise in the water table due to reduced catchment-wide transpiration rates (Bliss and Comerford 2002). This rise is disproportionately higher in DIS areas due to the already shallow groundwater table, resulting in drier ND areas and wetter DIS areas in clear-cut compared to undisturbed riparian zones.

\subsection{Temporal variation in greenhouse gas fluxes}

Greenhouse gas fluxes are strongly controlled by environmental factors that often fluctuate throughout the year. As we hypothesized, GHG fluxes had significant temporal variation associated with seasonal changes in soil temperature, groundwater level, and soil moisture, with peak gas emissions occurring in the wettest and/or warmest months. Carbon dioxide emission rates were greatest in the summer in both DIS and ND areas, with soil temperature explaining $30.0 \%$ of the variation. Soil moisture had the highest relative importance $(9.8 \%)$ for $\mathrm{CH}_{4}$ uptake, which was highest in the summer for DIS areas and in the spring for ND areas. The relationship between $\mathrm{CH}_{4}$ flux rate and soil moisture differed based on groundwater influence. At the ND areas, $\mathrm{CH}_{4}$ uptake decreased with increasing soil moisture, while in the DIS areas $\mathrm{CH}_{4}$ uptake increased with increasing soil moisture. Similarly, variation in $\mathrm{CH}_{4}$ fluxes from soils in a Pacific coastal temperature rainforest in North America were related to soil water content, with increased uptake rates with decreasing soil moisture in upland soils, and increased emission rates with increasing soil moisture in wet soils (Christiansen et al. 2016). Nitrous oxide emission rates peaked in the summer at both the DIS and ND areas, with soil temperature explaining $26.2 \%$ and soil moisture explaining $13.8 \%$ of the variation. Nitrous oxide fluxes have been found to peak at intermediate levels of soil moisture (Christiansen et al. 2012), and to have a positive relationship with flooding of the groundwater table (Mander et al. 2015).

Our results were in line with other temporal studies of riparian GHG flux rates. For example, seasonal differences in $\mathrm{CO}_{2}$ rates were correlated with soil temperature in riparian wetland ecosystems in northeast China (Sun et al. 2013). Carbon dioxide emission rates in a riparian floodplain forest in Indiana, USA showed a strong seasonal pattern, with peak rates in the spring and summer, and lowest rates in the fall 
and winter, significantly related to soil temperature (Jacinthe 2015). Soil moisture was determined to control the magnitude of potential $\mathrm{CH}_{4}$ fluxes in Pacific temperature rainforest of Canada, where wet forest soils produced significantly higher amounts of $\mathrm{CH}_{4}$ than upland forest soils, due to a greater abundance of $\mathrm{CH}_{4}$-producing Archaea (Christiansen et al. 2017). Soil temperature, soil moisture, and soil nitrogen levels were significantly related to $\mathrm{N}_{2} \mathrm{O}$ emissions, with peak $\mathrm{N}_{2} \mathrm{O}$ emissions observed in the summer from a riparian forest in southern Ontario, Canada (De Carlo et al. 2019)ndscapes.

\section{Conclusions}

In conclusion, we found that the seasonal variations in GHG fluxes from riparian soils alongside headwater streams were influenced to different degrees of importance by changes in soil moisture, soil temperature, and depth to the groundwater table. The seasonal trends in emission rates were typically similar at the DIS and ND areas, although there was consistently greater variability in greenhouse gas flux rates at the ND areas than the DIS areas. The summer months most often had peak emission rates, although the other seasons still had sizeable GHG contributions. Our results showed that seasonal fluctuations in greenhouse gas fluxes were primarily driven by soil temperature (for $\mathrm{CO}_{2}$ and $\mathrm{N}_{2} \mathrm{O}$ ) and soil moisture (for $\mathrm{CH}_{4}$ ). Although not significant, we found on average lower $\mathrm{CH}_{4}$ uptake and lower $\mathrm{CO}_{2}$ emissions in the DIS areas than the ND areas.

The results of this research further our understanding of the seasonal and spatial dynamics of GHG fluxes in riparian zones of headwater streams. To date, these dynamics have been understudied, despite the unique conditions and prevalence of riparian zones of headwater streams across many landscapes.

\section{Declarations}

\section{Acknowledgements}

We thank the European Commission and the Natural Sciences and Engineering Research Council (NSERC, Canada) for funding, in the frame of the collaborative international Consortium SOSTPRO financed under the 2016 Joint Call of the WaterWorks 2015 ERA-NET Cofund. This ERA-NET is an integral part of the 2016 Joint Activities developed by the Water and FACCE JPIs. We are grateful to NSERC and the University of British Columbia for additional support through scholarships and other funds. We appreciate the assistance of volunteers, field assistants, the Malcolm Knapp Research Forest staff, and members of the Stream and Riparian Research Lab, namely, Olivia Hester who helped extensively with the field work. We thank Lenka Kuglerová for her help with the groundwater discharge modelling. We also thank David Levy-Booth and Chun Chung Yeung for their advice on greenhouse gas monitoring, as well as countless others for their inputs and counsel.

\section{Funding}


This work was funded by the European Commission and the Natural Sciences and Engineering Research Council (NSERC, Canada), in the frame of the collaborative international Consortium SOSTPRO financed under the 2016 Joint Call of the WaterWorks 2015 ERA-NET Cofund. This ERA-NET is an integral part of the 2016 Joint Activities developed by the Water and FACCE JPIs. The University of British Columbia and NSERC provided additional support through scholarships and other funds.

\section{Conflicts of interest/Competing interests}

The authors have no conflicts of interest to declare that are relevant to the content of this article.

\section{Ethics approval}

Not applicable

\section{Consent to participate}

Not applicable

\section{Consent for publication}

All authors consent to the submission and publication of this manuscript

\section{Availability of data and material}

Data and other relevant materials are readily available on request.

\section{Code availability}

R programming code used for statistical analysis is available on request.

\section{Author's contributions}

Both authors contributed to the study conception and design. Teresa Silverthorn performed the research and analysis and wrote the first draft of the manuscript. John Richardson provided substantial input to the data analysis and commented on previous versions of the manuscript. Both authors read and approved the final manuscript.

\section{References}

Audet J, Elsgaard L, Kjaergaard C, Larsen SE, Hoffmann CC (2013) Greenhouse gas emissions from a Danish riparian wetland before and after restoration. Ecol Eng 57:170-182.

Bates D, Maechler M, Bolker B, Walker S (2015) Fitting linear mixed-effects models using Ime4. Journal of Statistical Software 67(1):1-48 
Bliss C, Comerford N (2002) Forest harvesting influence on water table dynamics in a Florida flatwoods landscape. Soil Sci Soc Am J 66(4):1344-1349

Brooks ME, Kristensen K, van Benthem KJ, Magnusson A, Berg CW, Nielsen A, et al (2017) glmmTMB balances speed and flexibility among packages for zero-inflated generalized linear mixed modeling. The R Journal 9(2):378-400

Christiansen JR, Vesterdal L, Gundersen P (2012) Nitrous oxide and methane exchange in two small temperate forest catchments-effects of hydrological gradients and implications for global warming potentials of forest soils. Biogeochemistry 107(1-3):437-454

Christiansen, J. R., Levy-Booth, D., Prescott, C. E., \& Grayston, S. J. (2016). Microbial and environmental controls of methane fluxes along a soil moisture gradient in a Pacific coastal temperate rainforest. Ecosystems, 19(7):1255-1270

Christiansen, J. R., Levy-Booth, D., Prescott, C. E., \& Grayston, S. J. (2017). Different soil moisture control of net methane oxidation and production in organic upland and wet forest soils of the Pacific coastal rainforest in Canada. Canadian Journal of Forest Research, 47(5):628-635

Collier SM, Ruark, MD, Oates, LG, Jokela WE, Dell CJ (2014).Measurement of greenhouse gas flux from agricultural soils using static chambers. J Vis Exp 90:e52110

Dalal RC, Allen DE (2008) Greenhouse gas fluxes from natural ecosystems. Aust J Bot 56(5): 369-407

De Carlo N, Oelbermann, M, Gordon A (2019) Spatial and temporal variation in soil nitrous oxide emissions from a rehabilitated and undisturbed riparian forest. J Environ Qual 48(3): 624-633

Fiedler, S., Höll, B. S., \& Jungkunst, H. F. (2005). Methane budget of a Black Forest spruce ecosystem considering soil pattern. Biogeochemistry, 76(1), 1-20.

Fisher K, Jacinthe P, Vidon, P, Liu X, Baker M. (2014) Nitrous oxide emission from cropland and adjacent riparian buffers in contrasting hydrogeomorphic settings. J Environ Qual 43(1):338-348

Furukawa Y, Inubushi K, Ali M, Itang A, Tsuruta H (2005) Effect of changing groundwater levels caused by land-use changes on greenhouse gas fluxes from tropical peat lands. Nutr Cycl Agroecosystems 71(1):8191

Giesler R, Högberg M, Högberg P (1998) Soil chemistry and plants in Fennoscandian boreal forest as exemplified by a local gradient. Ecology 79(1):119-137

Goodrick I, Connor S, Bird M, Nelson P (2016) Emission of $\mathrm{CO}_{2}$ from tropical riparian forest soil is controlled by soil temperature, soil water content and depth to water table. Soil Res 54(3):311-320 
Gregory SV, Swanson FJ, McKee WA, Cummins KW (1991) An ecosystem perspective of riparian zones. Bioscience, 41(8): 540-551

Gundersen P, Laurén A, Finér L, Ring E, Koivusalo H, Sætersdal M, et al (2010). Environmental services provided from riparian forests in the Nordic countries. Ambio, 39(8):555-566

Hazlett, P, Gordon A, Sibley P, Buttle J (2005) Stand carbon stocks and soil carbon and nitrogen storage for riparian and upland forests of boreal lakes in northeastern Ontario. For Ecol Manag 219(1):56-68

Hinshaw SE, Dahlgren RA (2016) Nitrous oxide fluxes and dissolved $\mathrm{N}$ gases $\left(\mathrm{N}_{2}\right.$ and $\left.\mathrm{N}_{2} \mathrm{O}\right)$ within riparian zones along the agriculturally impacted San Joaquin River. Nutr Cycl Agroecosystems 105(2):85-102

Hoffman G, Schadt E (2016) variancePartition: Interpreting drivers of variation in complex gene expression studies. BMC Bioinformatics, 17:483

Jacinthe P (2015) Carbon dioxide and methane fluxes in variably-flooded riparian forests. Geoderma 241:41-50

Jacinthe $\mathrm{P}$, Vidon $\mathrm{P}$ (2017) Hydro-geomorphic controls of greenhouse gas fluxes in riparian buffers of the white river watershed, IN (USA). Geoderma 301:30-41

Jacinthe P, Vidon P, Fisher K, Liu X, Baker M (2015) Soil methane and carbon dioxide fluxes from cropland and riparian buffers in different hydrogeomorphic settings. J Environ Qual 44(4):1080-1090

Jungkunst, H. F., Fiedler, S., \& Stahr, K. (2004). $\mathrm{N}_{2} \mathrm{O}$ emissions of a mature Norway spruce (Picea abies) stand in the Black Forest (southwest Germany) as differentiated by the soil pattern. Journal of Geophysical Research: Atmospheres, 109(D7):1-11

Kiffney, P. M., Richardson, J. S., \& Bull, J. P. (2003). Responses of periphyton and insects to experimental manipulation of riparian buffer width along forest streams. Journal of Applied Ecology, 40(6), 1060-1076.

Klinka K (1976) Ecosystem Units, their Classification, Interpretation and Mapping in the University of British Columbia Research Forest. Dissertation, University of British Columbia.

Klinka K, Chourmouzis C, Varga P (2005) Site units of the University of British Columbia Malcolm Knapp Research forest. Malcolm Knapp Research Forest, Maple Ridge, BC.

Kottek M, Grieser J, Beck C, Rudolf B, Rubel F (2006) World map of the Köppen-Geiger climate classification updated. Meteorol Z 15(3):259-263

Kravchenko A, Robertson $\mathrm{G}$ (2015) Statistical challenges in analyses of chamber-based soil $\mathrm{CO}_{2}$ and $\mathrm{N}_{2} \mathrm{O}$ emissions data. Soil Sci Soc Am J 79(1):200-211 
Kuglerová L, Jansson R, Ågren A, Laudon H, Malm-Renöfält B (2014) Groundwater discharge creates hotspots of riparian plant species richness in a boreal forest stream. Ecology 95(3):715-725

Lal R, Negassa W, Lorenz K (2015) Carbon sequestration in soil. Curr Opin Env Sust 15:79-86

Leith FI, Dinsmore KJ, Wallin MB, Billett M, Heal KV, Laudon H, et al (2015) Carbon dioxide transport across the hillslope-riparian-stream continuum in a boreal headwater catchment. Biogeosciences 12(6):1881-1892

Levy-Booth D, Giesbrecht I, Kellogg C, Heger T, D'Amore D, Keeling P, et al. (2019). Seasonal and ecohydrological regulation of active microbial populations involved in $\mathrm{DOC}, \mathrm{CO}_{2}$, and $\mathrm{CH}_{4}$ fluxes in temperate rainforest soil. The ISME Journal 13(4):950-963

Luo Y, Zhou X (2006) Soil respiration and the environment. Elsevier, Amsterdam

Mander Ü, Maddison M, Soosaar K, Teemusk A, Kanal A, Uri V, Truu J (2015) The impact of a pulsing groundwater table on greenhouse gas emissions in riparian grey alder stands. Environ Sci Pollut Res 22(4):2360-2371

Moore RD, Spittlehouse DL, Story A (2005) Riparian microclimate and stream temperature response to forest harvesting: A review 1. J Am Water Resour Assoc 41(4):813-834

Morishita T, Sakata T, Takahashi M, Ishizuka S, Mizoguchi T, Inagaki Y, et al (2007) Methane uptake and nitrous oxide emission in Japanese forest soils and their relationship to soil and vegetation types. Soil Sci Plant Nutr 53(5):678-691

Nag SK, Liu R, Lal R (2017) Emission of greenhouse gases and soil carbon sequestration in a riparian marsh wetland in central Ohio. Environ Monit Asses 189(11):580

Oertel C, Matschullat J, Zurba K, Zimmermann F, Erasmi S (2016) Greenhouse gas emissions from soilsA review. Chem Erde 76(3):327-352

Pihlatie M, Pumpanen J, Rinne J, Ilvesniemi H, Simojoki A, Hari P, Vesala T (2007) Gas concentration driven fluxes of nitrous oxide and carbon dioxide in boreal forest soil. Tellus B Chem Phys Meteorol 59(3):458-469

Pinay G, Bernal S, Abbott BW, Lupon A, Marti E, Sabater F, \& Krause S (2018). Riparian corridors: A new conceptual framework for assessing nitrogen buffering across biomes. Front Environ Sci 6(47)1-11

Poblador S, Lupon A, Sabaté S, Sabater F (2017) Soil water content drives spatiotemporal patterns of $\mathrm{CO}_{2}$ and $\mathrm{N}_{2} \mathrm{O}$ emissions from a Mediterranean riparian forest soil. Biogeosciences 14(18):4195-4208

R Core Team (2020) R: A language and environment for statistical computing. R Foundation for Statistical Computing, Vienna 
Ramey TL, Richardson JS (2017) Terrestrial invertebrates in the riparian zone: Mechanisms underlying their unique diversity. Bioscience 67(9):808-819

Richardson JS (2020) Headwater streams. In: Goldstein M, DellaSala D (ed). Encyclopedia of the world's biomes, vol. 4. Elsevier, Amsterdam, pp 371-378

Richardson JS, Danehy RJ (2007) A synthesis of the ecology of headwater streams and their riparian zones in temperate forests. For Sci 53(2):131-147

Richardson JS, Naiman RJ, Swanson FJ, Hibbs DE (2005) Riparian communities associated with Pacific Northwest headwater streams: Assemblages, processes, and uniqueness 1. J Am Water Resour Assoc 41(4):935-947

Silverthorn, T. K., \& Richardson, J. S. (2021). Forest management impacts on greenhouse gas fluxes from riparian soils along headwater streams. Ecosystems 24, 1-13.

Skinner C, Gattinger A, Muller A, Mäder P, Fließbach A, Stolze M, et al (2014) Greenhouse gas fluxes from agricultural soils under organic and non-organic management-A global meta-analysis. Sci Total Environ 468:553-563

Soosaar K, Mander Ü, Maddison M, Kanal A, Kull A, Lõhmus K, et al (2011) Dynamics of gaseous nitrogen and carbon fluxes in riparian alder forests. Ecol Eng 37(1):40-53

Sun Q, Shi K, Damerell P, Whitham C, Yu G, Zou C (2013) Carbon dioxide and methane fluxes: Seasonal dynamics from inland riparian ecosystems, northeast China. Sci Total Environ 465: 48-55

Tufekcioglu A, Raich JW, Isenhart TM, Schultz RC (2001) Soil respiration within riparian buffers and adjacent crop fields. Plant Soil 229(1):117-124

Vidon P, Marchese S, Welsh M, McMillan S (2015) Short-term spatial and temporal variability in greenhouse gas fluxes in riparian zones. Environ Monit Asses 187(8):503

Vidon P, Welsh M, Hassanzadeh Y (2018) Twenty years of riparian zone research (1997-2017): Where to next? J Environ Qual 28(2):248-260

Zuur A, leno E, Smith G (2007) Analysing ecological data. Springer, New York

\section{Table}


Table 1 Characteristics of riparian study sites alongside headwater streams in Malcolm Knapp Research Forest, British Columbia, Canada

\begin{tabular}{lcc}
\hline & Mike & Upper East \\
\hline Stream bankfull width $(\mathrm{m})$ & 1.97 & 4.14 \\
Catchment area (ha) & 39.4 & 37.0 \\
\hline Elevation $(\mathrm{m})$ & 267 & 311 \\
\hline Reach length $(\mathrm{m})$ & 72 & 54 \\
\hline Bank slope $\left(^{\circ}\right)$ & 7 & 29 \\
\hline Stream slope $\left(^{\circ}\right)$ & 5 & 7 \\
\hline
\end{tabular}

\section{Figures}



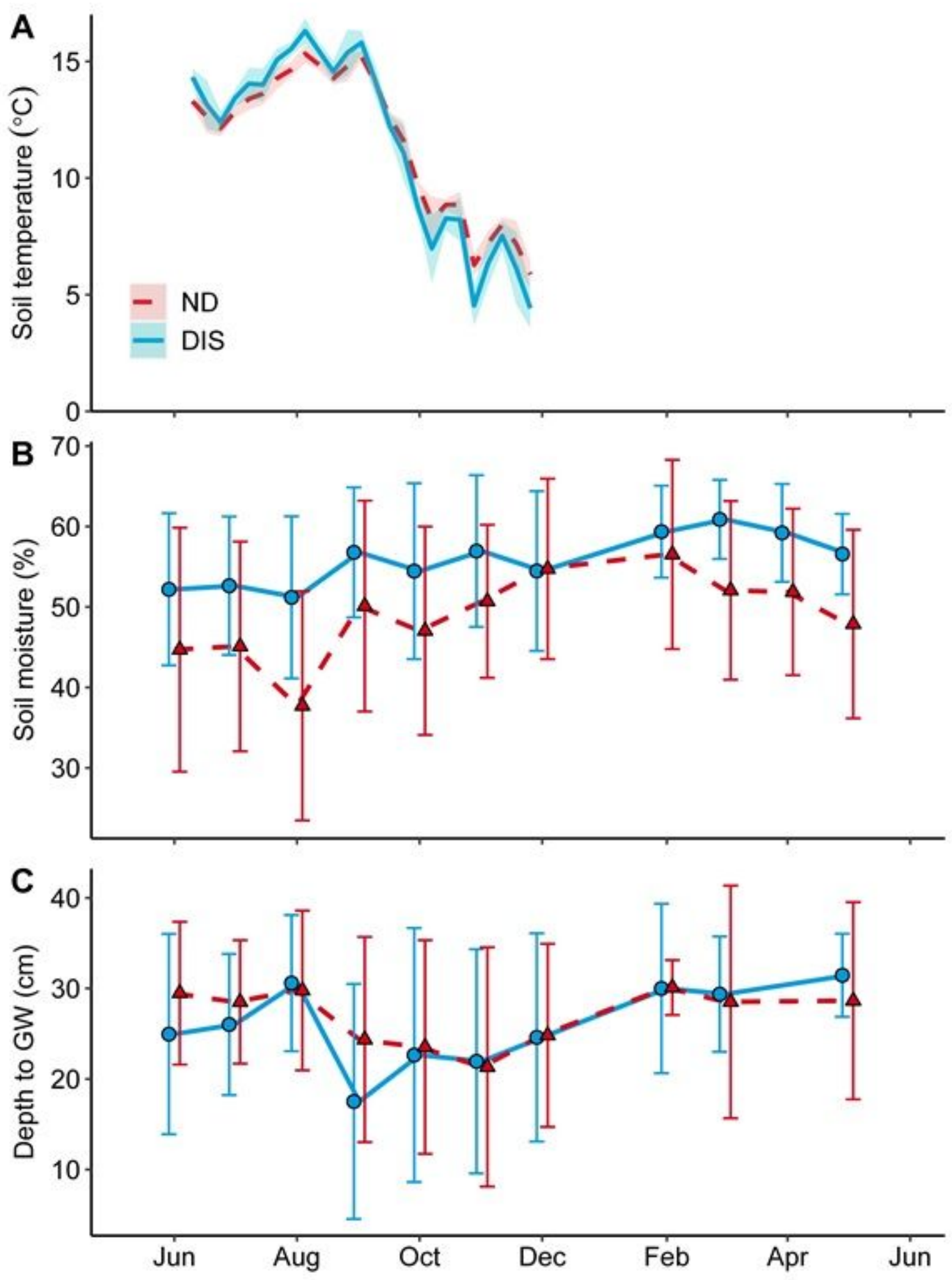

Figure 1

Environmental variables measured over time at groundwater discharge (DIS) and non-groundwater discharge (ND) areas in the riparian zone of two headwater streams in coastal British Columbia (A-C). A) Mean daily soil temperature measured $\sim 10 \mathrm{~cm}$ below the soil surface from June 2019 to November 2019 (see Fig. A.1 in Supplementary Information for mean soil temperature by site for the entire study period). B) Soil moisture measured as mean volumetric soil water content (\%) from May 2019 to May 2020. C) 
Mean depth to the groundwater table $(\mathrm{cm})$ from May 2019 to May 2020. The shaded area (A) and error bars $(B$ and $C)$ indicate standard deviation. For $B$ and $C$, the lines connecting the points are for visual effect only and are not meant to indicate continuous measurements
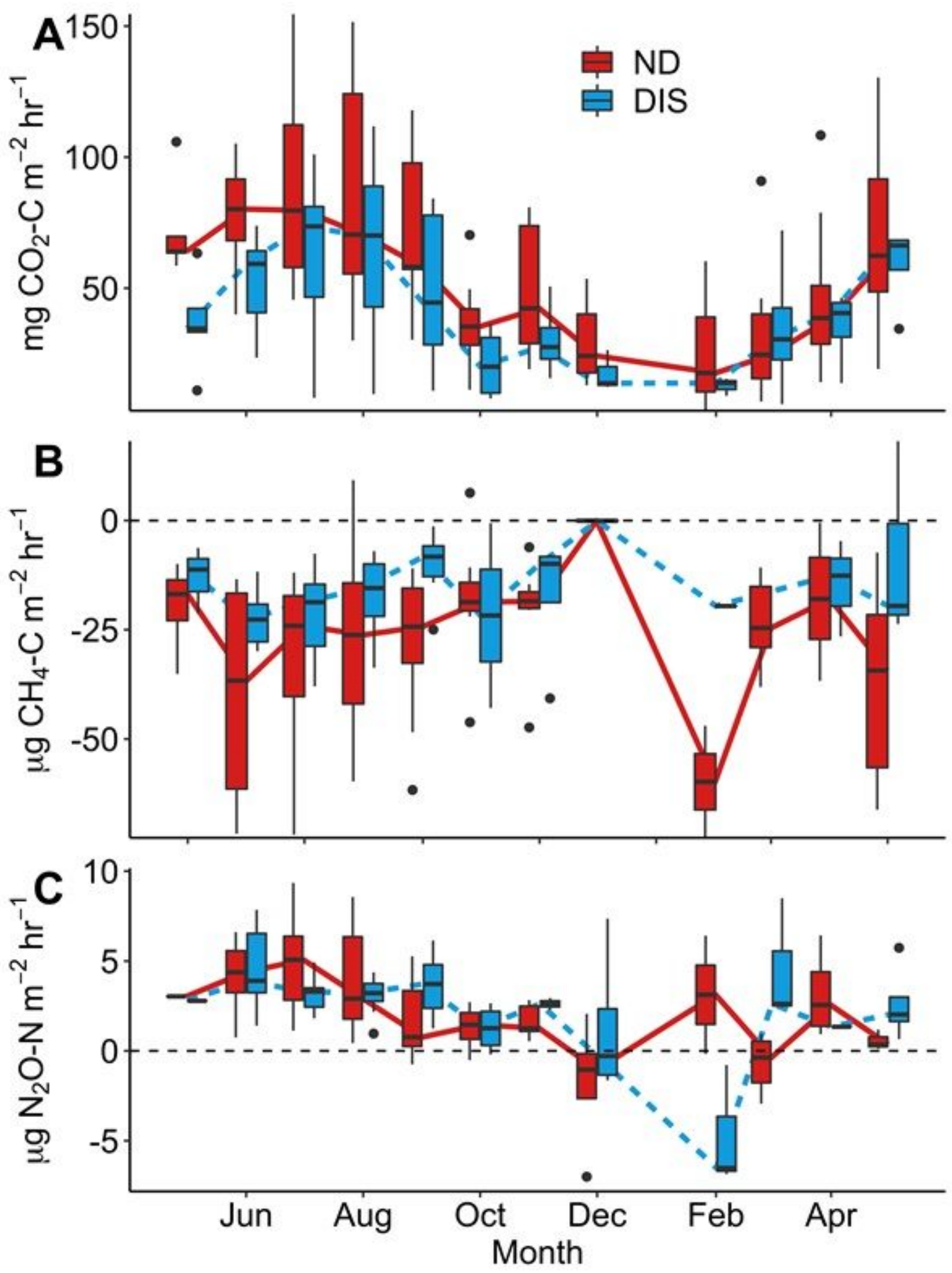

Figure 2

Riparian forest soil A) carbon dioxide (mg CO2-C m-2 h-1), B) methane ( $\mu \mathrm{g} \mathrm{CH} 4-\mathrm{C} \mathrm{m}-2 \mathrm{~h}-1$ ), and C) nitrous oxide ( $\mu \mathrm{g}$ N2O-N m-2 h-1) flux rates from groundwater discharge (DIS) and non-groundwater discharge 
(ND) areas of forested riparian areas alongside two headwater streams in the Pacific coastal temperate rainforest of British Columbia from May 2019 to May 2020. Boxplots display the median, 25th and 75th percentiles, whiskers (1.5 times the IQR), and individual outliers (dots)

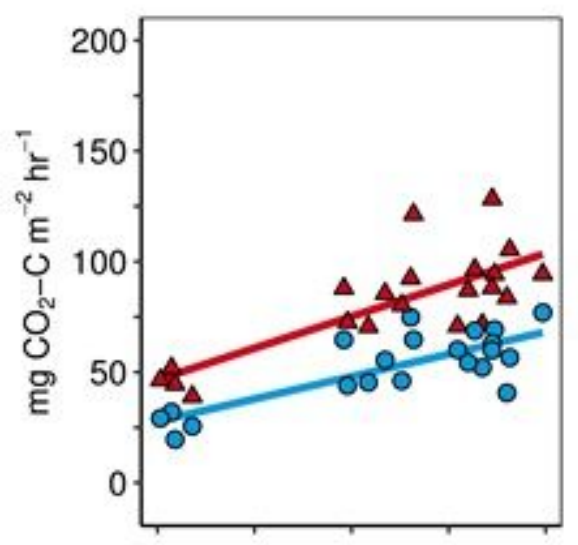

$\sim$ DIS $\triangle$ ND
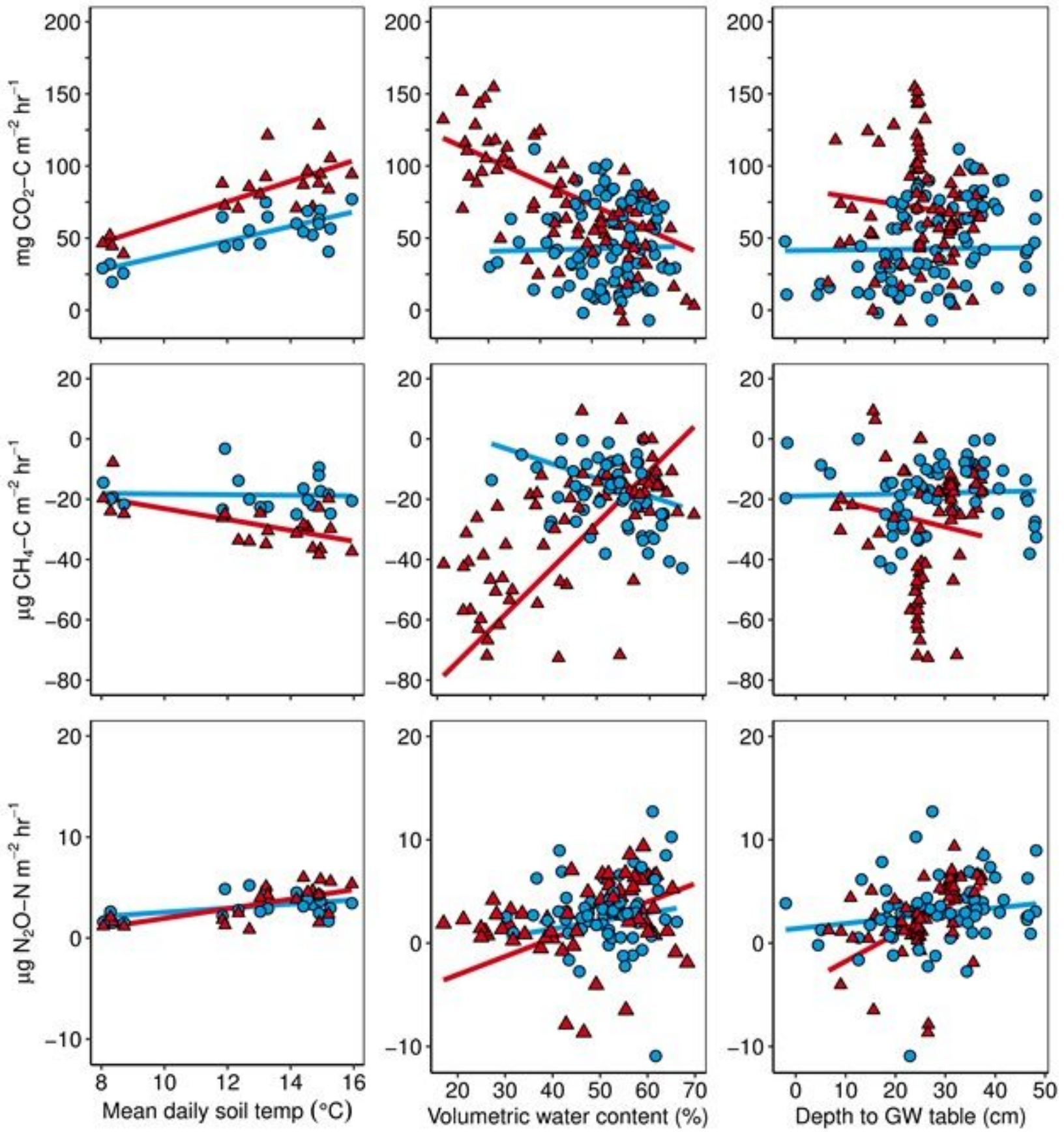

Figure 3

Relationships between greenhouse gas fluxes from riparian soils along headwater streams in coastal British Columbia and the environmental variables of daily mean soil temperature $\left({ }^{\circ} \mathrm{C}\right)$, mean volumetric water content (\%), and mean depth to groundwater table $(\mathrm{cm})$, by site. Trend lines for water content and depth to groundwater are based on LME models accounting for autocorrelation, and the trend lines for soil temperature are linear regressions due to the limited data 


\section{Supplementary Files}

This is a list of supplementary files associated with this preprint. Click to download.

- SupplementaryInformation.pdf 